\title{
Mortality trends and potential years of life lost due to ovarian cancer in Mexico, 2000-2014
}

\author{
Juan Jesús Sánchez-Barriga
}

Secretaria de Salud, Directorate General of Epidemiology, Directorate of Operative Research in Epidemiology, Ciudad de México, Mexico

\begin{abstract}
Introduction: In Mexico, ovarian cancer accounting for $5.3 \%$ of cancer diagnoses in all age groups and $21 \%$ of gynecological cancers and it has had a steady increase in the last three decades. Objective: To determine mortality trends from ovarian cancer and potential years of life lost (PYLL) by state and socioeconomic region of Mexico between 2000 and 2014. Method: Records of ovarian cancer were obtained from the National Institute of Statistics and Geography. ICD-10 codes corresponding to ovarian cancer as the basic cause of death were identified. Mortality rates and YPLL rates were calculated by nationwide, states and socioeconomic region. Results: Between 2000 and 2014, age-adjusted rates per 100,000 women increased from 3.3 to 4.1. The highest mortality rates were identified in region 7, in Chihuahua, Baja California Sur, Colima, Quintana Roo, Zacatecas, Sonora, Coahuila, Aguascalientes and Queretaro. The highest rates of PYLL due to ovarian cancer were recorded in regions 7, 5 and 6, Nayarit, Baja California Sur, Zacatecas, Colima, Tlaxcala, Oaxaca, Quintana Roo, Coahuila, Aguascalientes and Queretaro. Conclusions: Mexico's socioeconomic region 7 had the highest rates of PYLL and mortality from ovarian cancer.
\end{abstract}

KEY WORDS: Ovarian cancer. Mortality. Potential years of life lost.

\section{Introduction}

Ovarian cancer $(\mathrm{OC})$ is the seventh most common neoplasm in women and the eighteenth most frequent in the world. Approximately 239000 cases were recorded in 2012, which accounted for almost $4 \%$ of all new cancer cases of in women (2\% of total cases). $\mathrm{OC}$ incidence rates are higher in high-income countries than in those with medium and low income. In Central and Eastern Europe, in 2012, the age-standardized incidence rate was 11 per 100000 women and in some parts of Africa it was less than 5. In the United Kingdom it was 11.7 and in the United States 8, in Brazil 5.2 and in China 4.1. ${ }^{1}$

During the last two decades, OC mortality rates have shown a trend towards a balance or a decrease in several high-income European and North American countries, where they were high. The advance in OC diagnosis and treatment, as well as the use of oral contraceptives may have influenced, particularly in high-income countries. There are persistent and substantial differences in OC patterns and trends in the world. In 2012, in the world, the country with the highest mortality was Lithuania, with a mortality rate of 7.1 per 100000 women, adjusted for age with the world population; the country with the lowest mortality rate was the Republic of Korea with 2.2. That same year, in Europe, the countries with the highest OC mortality rates were Lithuania (7.1), Ireland (7.09) and Latvia (6.64), and the countries with the lowest mortality were Spain (3.69), Greece (3.5) and Portugal (3.03). In the region of Asia, Australia and Oceania, the countries with the highest mortality in 2011 were New Zealand (4.93) and Australia (4.27) and those that had the lowest mortality were Hong Kong (2.46) and the Republic of Korea (2.26). In the region of the Americas, the countries with the highest mortality in 2011 were Canada (4.95) and in 2012, the United States (4.85); those that had the lowest mortality in this continent in 2012 were Cuba (3.07) and Brazil (2.8). ${ }^{2}$
Correspondence:

Juan Jesús Sánchez-Barriga

E-mail: jsanchez@dgepi.salud.gob.mx
Date of reception: 26-07-2017

Date of acceptance: 18-01-2018

DOI://dx.doi.org/10.24875/GMM.M18000170
Gac Med Mex. 2018;154:367-375

Contents available at PubMed www.gacetamedicademexico.com 
In Mexico, OC accounts for $5.3 \%$ of cancer diagnoses all age groups and $21 \%$ of gynecological cancers. In 2004, there were 473417 deaths recorded, out of which malignant tumors were the third cause of death with 31443 deaths; $4.6 \%$ of deaths in total female population were OC-related. ${ }^{3} \mathrm{~A}$ sustained annual increase of $1.4 \%$ in OC mortality has been observed from 1980 to 2011. In comparison with Canada, the United States, Argentina and Uruguay, Mexico has an intermediate ovarian cancer mortality rate. ${ }^{4}$

The purposes of this study were to determine OC mortality trends and associated years of potential life lost (YPLL) per state and socioeconomic region of Mexico in the 2000-2014 period.

\section{Methods}

A mortality trends study design was used. OC-associated mortality records for the 2000-2014 period were obtained from the National Institute of Statistics and Geography (INEGI - Instituto Nacional de Estadística y Geografía). ${ }^{5}$ This information is collected from death certificates issued in the country.

All individual mortality records where the cause of death was OC were included. The codes of the International Classification of Diseases, $10^{\text {th }}$ Edition, corresponding to OC as cause of death (C56) were identified. ${ }^{6}$

Nation-wide mortality rates were obtained, raw and age-adjusted, per 100000 women, taking the world population as the standard ${ }^{7,8}$ Age-adjusted mortality rates per 100000 women of each state of residence and of each one of the 7 socio-economic regions established by INEGI were also obtained (Table 1). ${ }^{9}$ The population that was used for rate adjustments was the national population, estimated by the National Population Council for the years 2000- 2014. ${ }^{10}$

Mean annual change was calculated by means of simple linear regression analysis. This analysis was used to determine whether in the study period there was a decrease or increase in OC mortality rate, both in gross rates and in mortality rates adjusted by age with the world population per 100000 women. ${ }^{11}$

YPLL rates were also determined per 100000 women adjusted for age according to the state of residence and socioeconomic region. Five-year age groups were used; the age limits that were used for calculation were the following: lower limit was 1 year and upper, 70 years for YPLL rates calculation, which were expressed per 100000 women.12,13 YPLL age-adjusted rates were calculated separating the years lost in the respective age groups, based on individual age;
Table 1. Socioeconomic regions of Mexico

\begin{tabular}{|c|c|c|}
\hline $\begin{array}{l}\text { Socioeconomic } \\
\text { regions }\end{array}$ & States & $\infty$ \\
\hline 1 & Chiapas, Guerrero, Oaxaca & 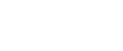 \\
\hline 2 & $\begin{array}{l}\text { Campeche, Hidalgo, Puebla, San L } \\
\text { Potosí, Tabasco, Veracruz }\end{array}$ & Luis \\
\hline 3 & $\begin{array}{l}\text { Durango, Guanajuato, Michoacán, } \\
\text { Zacatecas }\end{array}$ & Tlaxcala, \\
\hline 4 & $\begin{array}{l}\text { Colima, Estado de México, Morelos } \\
\text { Querétaro, Quintana Roo, Sinaloa, }\end{array}$ & $\begin{array}{l}\text { S, Nayarit, } \\
\text { Yucatán }\end{array}$ \\
\hline 5 & $\begin{array}{l}\text { Baja California, Baja California Sur, } \\
\text { Chihuahua, Sonora, Tamaulipas }\end{array}$ & $r \frac{\frac{c}{n}}{\frac{0}{2}}$ \\
\hline 6 & $\begin{array}{l}\text { Aguascalientes, Coahuila, Jalisco, } \\
\text { León }\end{array}$ & Nuevo \\
\hline 7 & Ciudad de México & ○ \\
\hline
\end{tabular}

age-specific rates were calculated based on the population age group. These age-specific YPLL rates were weighted using the national population as the standard population and a single rate was calculated. The YPLL calculated rate was obtained with the following formula:13

$$
\begin{aligned}
& \text { Age -adjusted YPLL rates }= \\
& \sum_{i=1}^{69} a i\left(\frac{d i}{p i}\right)\left(\frac{P i r}{N r}\right) \times 100000
\end{aligned}
$$

Where

$p i=$ number of people of $i$ age in current population.

Pir $=$ number of people of $i$ age in the reference population.

$\mathrm{Nr}=$ number of people between 1 and 70 years in the reference population.

$d i=$ number of deaths between ages $i$ and +1 .

$a i=$ years of life remaining until age 70 , when dying between ages $i$ and $i+1=70-(i+0.5)$.

The 7 socio-economic regions were defined by INEGI according to the $12^{\text {th }}$ General Population and Housing Census, with the observed differences in social and economic conditions of the population in Mexico being presented. All 32 states are grouped in the 7 socio-economic regions according the the following indicators of well-being: education, occupation, health, housing and employment. States with similar characteristics were classified in the same region and each region is different from the other. According to the used indicators, socio-economic conditions had a rank in ascending order, from region 1, the least favorable, to region 7 , the most favorable. The purpose of the methodology used for establishing the regions 


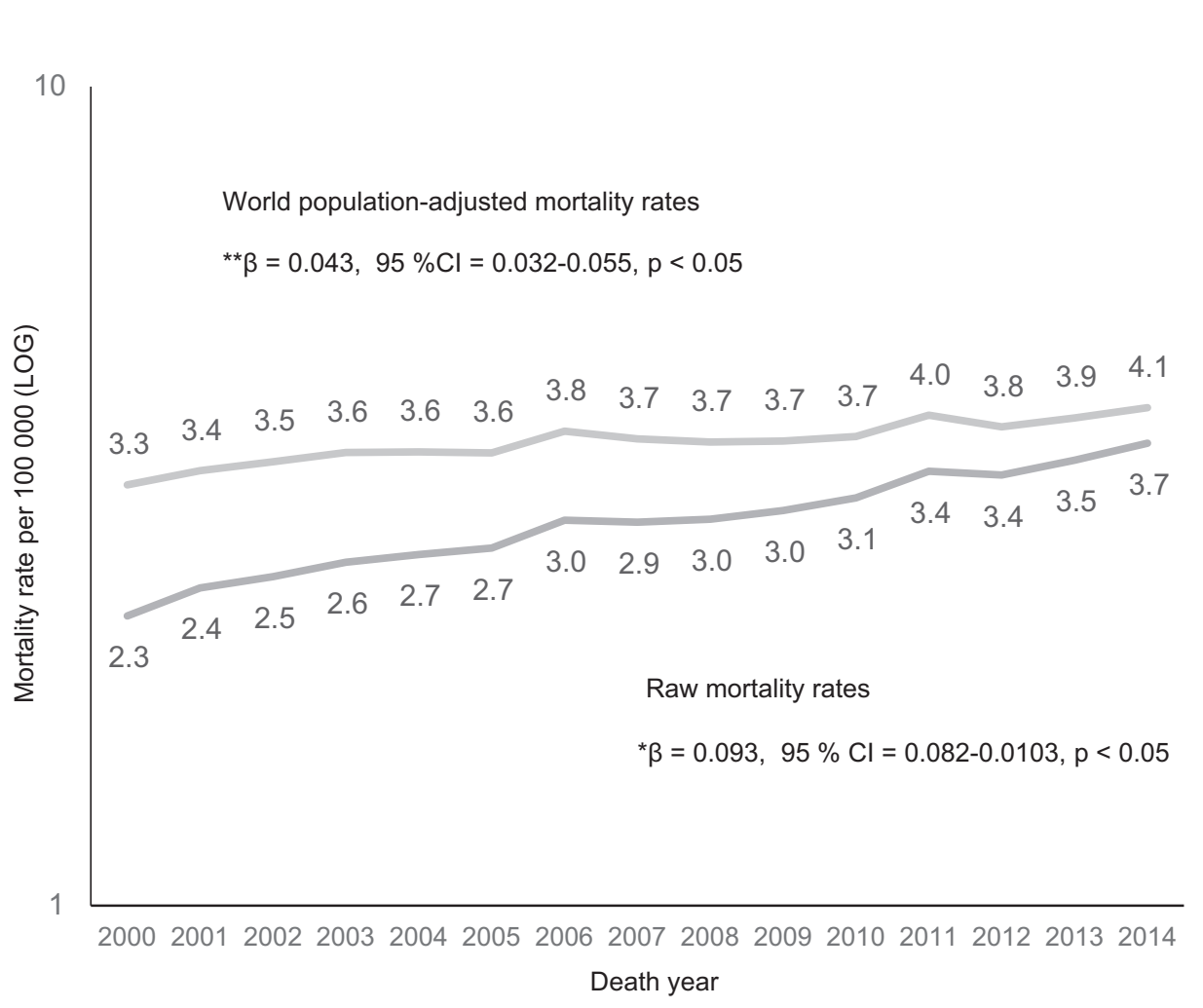

Figure 1. Ovarian cancer mortality in Mexico, 2000-2014. Gross mortality rate per 100000 women. Age-adjusted rate by direct method, standardized with world population per 100000 women. Source: Analysis by the author of data obtained from the National Institute of Statistics and Geography and from the National Population Council: population estimates, 1990-2010 period and population projections for 2010-2030. *Mean annual change per 100,000 women/year and $95 \% \mathrm{Cl}$ and p-value for crude mortality rates in the 2000-2014 period. **Mean annual change per 100,000 women/year and $95 \% \mathrm{Cl}$ and p-value for standardized mortality rates in the 2000-2014 period.

was the creation of strata with minimal variation and, this way, by adhering to an established similarity criterion, group the elements of greater similarity, thus allowing the distinction between one region and another. The used techniques included Mahalonobis distances and a combination of factorial analysis and the K-means algorithm. ${ }^{9}$

The records were managed with the Access 2013 program. For the calculation of age-adjusted mortality rates and YPLL rates, the Epidat program, version 3.1, was used..$^{14}$

\section{Results}

In Mexico, in the 2000-2014 period, 498071 women died due to malignant neoplasms and, of these, 25047 died from OC (5.02\% of total). In 2000, there were 1157 deaths, and in 2014, 2249 due to this neoplasm. In the study period, the mortality rate standardized by age with the world population per 100000 women increased from 3.3 to 4.1 , with a percentage change of $24.2 \%$ and mean annual change of 0.043 , $95 \% \mathrm{Cl}=0.32-0.55$ (Fig. 1).
With increasing age, OC mortality did increase. Women aged between 55 and 59 years showed the highest mortality (3089 cases, $12.3 \%$ ) (Fig. 2). Age group-specific mortality trends did increase between 2000 and 2014, except in the $<30$ years group. The group that showed the highest mortality increase was the 51 to 60 years group (data not shown).

In the period, 31 states had an increase in OC mortality trends; the only one that showed no changes was Nayarit. The states with the highest mortality rates were Chihuahua in the year $2000 \quad(3.8,95 \%$ $\mathrm{Cl}=2.75-4.85)$, Baja California Sur in 2001, 2002, 2007 and 2009 (5.36, $95 \% \mathrm{Cl}=2.14-8.58 ; 4.27,95 \%$ $\mathrm{Cl}=1.3-7.25 ; 6.03,95 \% \mathrm{Cl}=2.8-9.27 ; 4.44,95 \%$ $\mathrm{Cl}=1.76-7.11$, respectively); Colima in 2003, 2005, 2011 and $2012(4.75,95 \% \mathrm{Cl}=2.25-7.24 ; 5.28,95 \%$ $\mathrm{Cl}=2.69-7.87 ; 4.46,95 \% \mathrm{Cl}=2.26-6.72 ; 4.36,95 \%$ $\mathrm{Cl}=2.15-6.57$, respectively); Quintana Roo in 2004 (4.26, $95 \% \mathrm{Cl}=1.63-6.89)$; Zacatecas in $2006(4.39,95 \% \mathrm{Cl}=2.85-5.9)$; Sonora in 2008 (3.98, 95\% Cl = 2.88-5.07); Coahuila in 2010 (4.41, $95 \% \mathrm{Cl}=3.29-5.53)$; Aguascalientes in $2013(4.6,95 \% \mathrm{Cl}=2.86-6.34)$ and Querétaro in $2014(5.2,95 \% \mathrm{Cl}=3.72-6.68)$ (Table 2). 

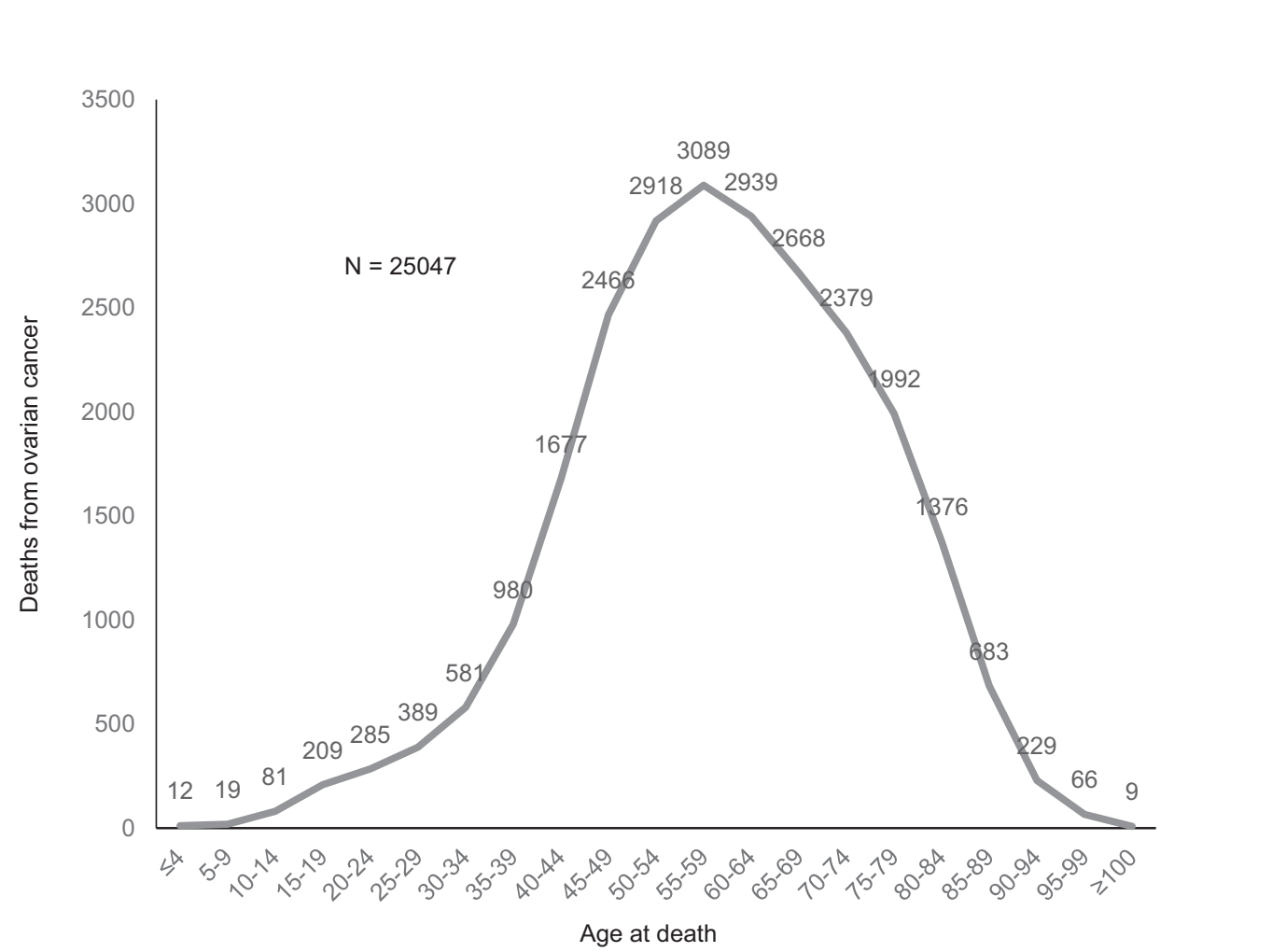

Figure 2. Ovarian cancer mortality by age-group, Mexico, 2000-2014. Analysis of the National Institute of Statistics and Geography database.

The states with the lowest mortality rates were Colima in 2000 and $2002(1.01,95 \% \mathrm{Cl}=-0.14-2.16$ and $1.34,95 \% \mathrm{Cl}=0.02-2.67$, respectively); Nayarit in 2001, 2007, 2009 and $2013(1.14,95 \% \mathrm{Cl}=0.22-2.05$; $1.3,95 \% \mathrm{Cl}=0.34-2.26 ; 1.79,95 \% \mathrm{Cl}=0.68-2.91$; 1.3, $95 \% \mathrm{Cl}=0.4-2.21$, respectively), Yucatán 2003 (1.36, $95 \% \mathrm{Cl}=$ 0.62-2.1; Guerrero in 2004 (1.03, $95 \% \mathrm{Cl}=0.54-1.52) ;$ Tabasco in 2005 and $2014(1.44$, $95 \% \mathrm{Cl}=0.65-2.23 ; 1.89,95 \% \mathrm{Cl}=1.08-2.71$, respectively); Quintana Roo in $2006(0.72,95 \% \mathrm{Cl}$ $=-0.14-1.58) ;$ Campeche in $2008(1.28,95 \% \mathrm{Cl}=$ 0.15-2.4), Chiapas in $2010(1.36,95 \% \mathrm{Cl}=0.86-1.86)$; Baja California Sur in $2011(1.68,95 \% \mathrm{Cl}=0.2-3.15)$ and Zacatecas in $2012(1.66,95 \% \mathrm{Cl}=0.79-2.54)$ (Table 2).

The socioeconomic region that showed the highest CO mortality rate in the 2000-2014 period was region 7, except in 2013, in which region 6 had the highest mortality. In 2000 and 2014, the mortality rates for region 7 were $3.35,95 \% \mathrm{Cl}=2.88-3.83$ and $4.92,95 \%$ $\mathrm{Cl}=4.36-5.49$, respectively; for region 6 , the mortality rate in 2013 was $4.28,95 \% \mathrm{Cl}=3.84-4.72$ (Table 3).

Socioeconomic region 1 had the lowest OC mortality rate in the study period, except in 2001, in which region 2 showed the lowest mortality rate. Mortality rates for region 1 in 2000 and 2014 were 1.57, 95\% $\mathrm{Cl}=1.24-1.91$ and $2.65,95 \% \mathrm{Cl}=2.24-3.06$, respectively; for region 2, in 2001 it was $1.94,95 \% \mathrm{Cl}$ $=1.67-2.21$ (Table 3).

The states with the highest YPLL rate in the study period ere Nayarit in year 2000 (41.6), Baja California Sur in 2001 and 2007 (86.2 and 71.2, respectively), Zacatecas in 2002 and 2006 (57.5 and 76.7, respectively), Colima in 2003, 2004 and 2010 (81.6, 74.1 and 70.4, respectively), Tlaxcala in 2005 (79.6), Oaxaca in 2008 (54.4), Quintana Roo in 2009 (54.5), Coahuila in 2011 and 2012 (64 and 63.8, respectively), Aguascalientes in 2013 (77.8) and Querétaro in 2014 (77.4) (data not shown).

The states with the lowest YPLL rate in the study period were Yucatan in 2000 and 2003 (19 and 15.9, respectively), Guerrero in 2001 and 2014 (15.1 and 26.3, respectively), Quintana Roo in 2002 and 2006 (11 and 11.2, respectively), Nayarit in 2004, 2009 and 2013 (7.2, 27 and 6.1, respectively), Tabasco in 2005 (16.9), Campeche in 2007 and 2010 (18.4 and 15 , respectively), Chiapas in 2008 (20.7), Aguascalientes in 2011 (23.3) and Zacatecas in 2012 (13.8).

The regions with the highest YPLL rates in the study period were region 7 (in years 2000-2004, 2006-2012 and 2014, respectively) and regions 5 (2005) and 6 (2013). YPLLs for region 7 in 2000 and 2014 were 37.9 and 67.4 , respectively; for region 5 it was 41.4 in 2005 and for region 6 it was 54.6 in 2013. 


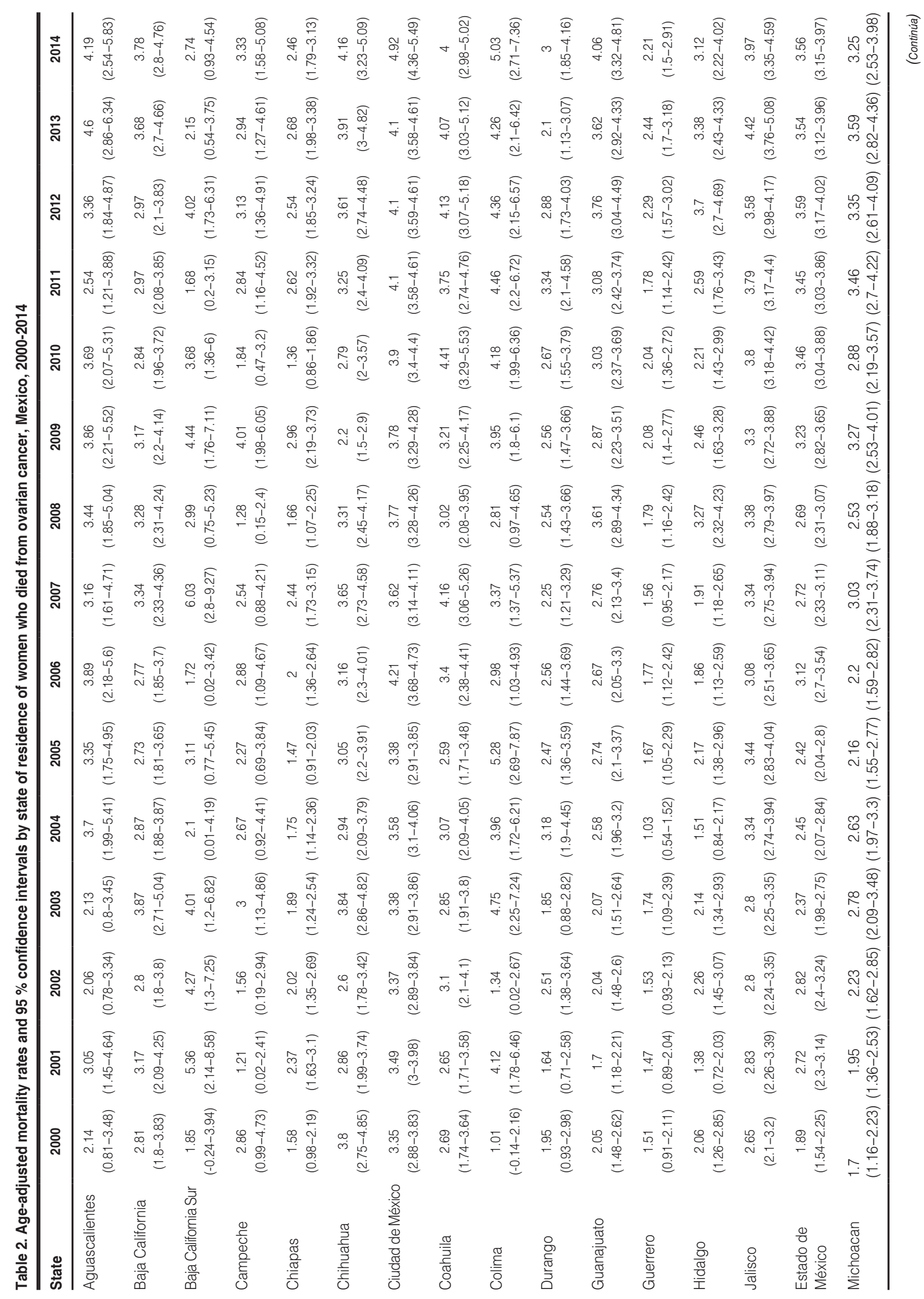




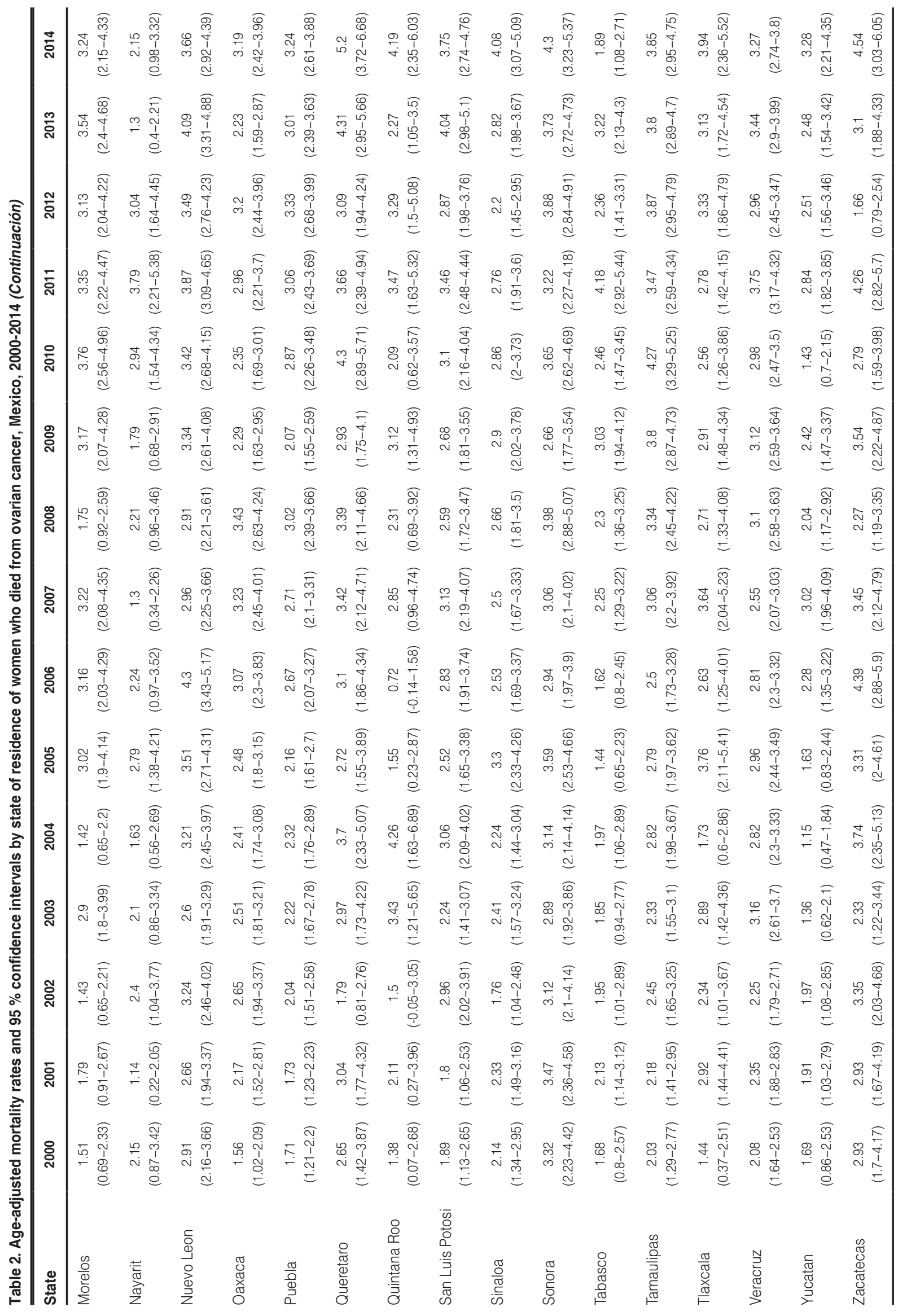




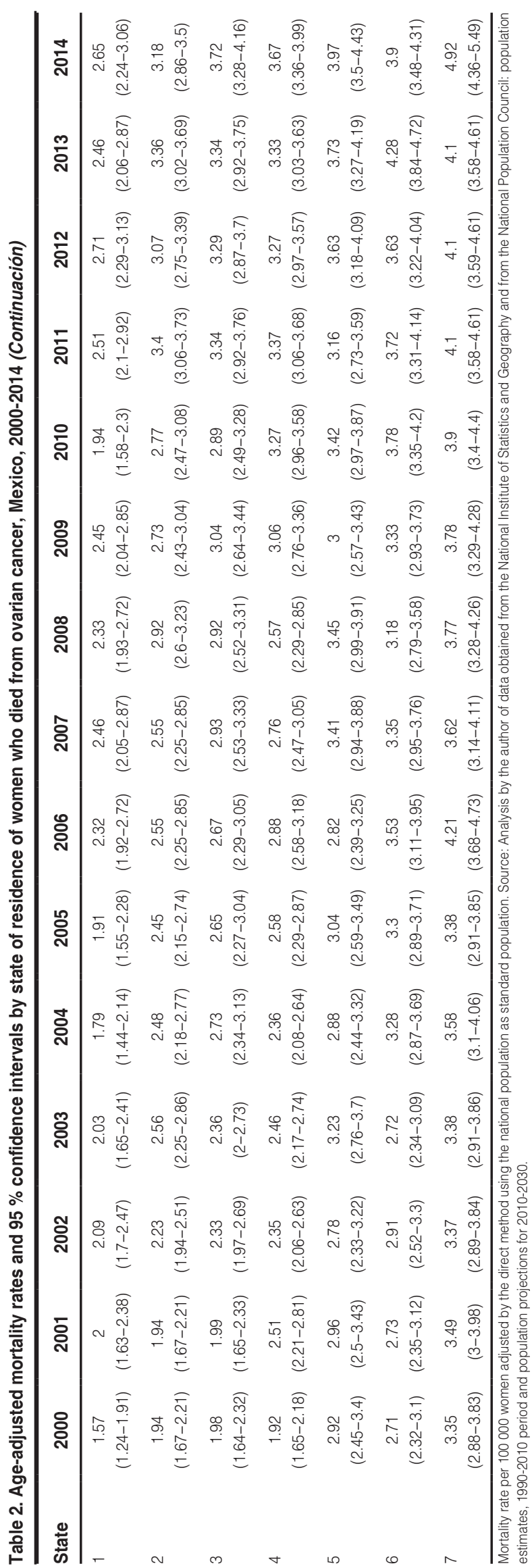

The regions with the lowest YPLL rate in the study period were regions 1 (in 2000, 2001, 2004, 2005, 2008 and 2010-2014, respectively), region 5 (in 2002, 2006, 2007 and 2009, respectively) and region 4 (2003). YPLLs for region 1 were in 22.4 and 37.5 in 2000 and 2014, respectively; for region 5 , they were 30 and 35.5 , respectively in 2002 and 2009; and for region 4, 32.3.

\section{Discussion}

In the studied period, OC mortality rate standardized by age with the world population per 100000 women increased from 3.3 to 4.1, with a percentage change of $24.2 \%$ and a mean annual change of $0.043,95 \%$ $\mathrm{Cl}=0.32-0.55$ (Fig. 1). In the world, in the last two decades, the rates of OC-related mortality have stabilized or decreased. However, there are persistent and substantial differences in OC patterns and trends. ${ }^{2}$ In Mexico and in other countries, the sustained increase in mortality rates of this cancer might be due to late diagnosis, the absence of highly curative chemotherapy and ovarian tumors high degree of molecular heterogeneity, a finding that is a consequence of typical high tumor burden in patients at this cancer's presentation. 15

In high-income countries of North America and Europe, one of the factors that has been observed to have contributed to $\mathrm{OC}$ decrease is the widespread use of oral contraceptives. ${ }^{2}$ The use of oral contraceptives by women is associated with a 40 to $50 \%$ reduction in OC risk. ${ }^{16}$ In Mexico, there is no information regarding the use of oral contraceptives and their impact on OC.

In this study, the highest OC mortality was identified to occur in the 55 to 59 years' group (Fig. 2). The risk for suffering from $\mathrm{OC}$ has been observed to increase with age. ${ }^{1}$ Factors that could be related to the presentation of $\mathrm{OC}$ as age increases are incessant ovulation, stimulation by gonadotropins and mutations. The ovaries of older women have been observed to show more morphological changes than those of younger women. Ovarian aging is characterized by ovarian morphological changes such as papillomatosis, invaginations of the ovarian superficial epithelium, inclusion cysts and epithelial stratification, with these alterations, which might be pre-neoplastic lesions, being found more often in postmenopausal and perimenopausal women. During ovulation, ovarian damage can occur, and in post-ovulation there is cell is proliferation, which is produced to repair the ovarian surface epithelium, and these mechanisms can generate mutations that accumulate in epithelial cells and, finally, participate in the formation of tumors. The gonadotropin stimulation 
theory posits that gonadotropins initiate each ovulation and persist at high levels for many years even after menopause. Gonadotropins stimulate ovarian surface epithelial cells and induce cell transformation. ${ }^{17}$

Another factor related to $\mathrm{OC}$ increase by age increase are mutations. Genomic studies indicate that approximately 10 to $12 \%$ of ovarian carcinomas are characterized by mutations in the BRCA1 and BRCA2 genes; ${ }^{15}$ these mutations occur at an advanced age, reaching their highest frequency in the 50 to 59 years' group. ${ }^{18}$

Socioeconomic region 7, which corresponds to Mexico City, showed the highest OC-related mortality rate in the 2000-2014 period. Family history of ovarian cancer, early menarche, late menopause, nulliparity, infertility, polycystic ovarian syndrome, hormone replacement therapy in postmenopausal women, exposure to asbestos, talcum powder, endometriosis, pelvic inflammatory disease, obesity, high consumption of saturated fats, sedentary lifestyle and smoking (it increases the possibilities of mucinous $\mathrm{OC}$ by 50 $\%$ ) have been reported to be risk factors for suffering from OC..$^{19}$ Some risk factors that might be associated with ovarian cancer mortality in Mexico City are obesity, high consumption of saturated fats, sedentary lifestyle and smoking. In the National Health and Nutrition Survey, Mexico City was observed to have one of the highest prevalences of overweight and obesity in the country; ${ }^{20}$ women had a higher prevalence of overweight (BMI $\geq 25 \mathrm{~kg} / \mathrm{m}^{2}$ ) than men than men (BMI $29.5 \mathrm{~kg} / \mathrm{m}^{2}$ versus $27.9 \mathrm{~kg} / \mathrm{m}^{2}$, respectively). The prevalence of obesity (BMI $\geq 30 \mathrm{~kg} / \mathrm{m}^{2}$ ) was also higher in women than in men ( $41 \%$ versus $27 \%$, respectively, $\mathrm{p}<0.00001) .{ }^{21}$ In Mexico City, a higher prevalence of physical inactivity than in the rest of the country is also observed (41.4\%). ${ }^{20}$ Physical inactivity in Mexico City has been reported at $82 \%$ in women and $71 \%$ in men. ${ }^{21}$ Mexico City has one of the highest prevalences of smoking in the country. The Smoking in Young People in Mexico Survey ${ }^{22}$ reported that Mexico City had the highest prevalence of young smokers $(27.8 \%) ; 58.3 \%$ of women had the smoking habit.

Region 7 is the region with the best socio-economic conditions of the country; in the study period, it showed the highest YPLL (Fig. 3) and OC-related mortality rates (Table 3).

YPLLs are one of the measures of the relative impact of several diseases and health conditions in society, which illustrate the losses suffered by society as a consequence of young people's death or premature deaths. Death is considered to be premature when it occurs before a certain predetermined age,

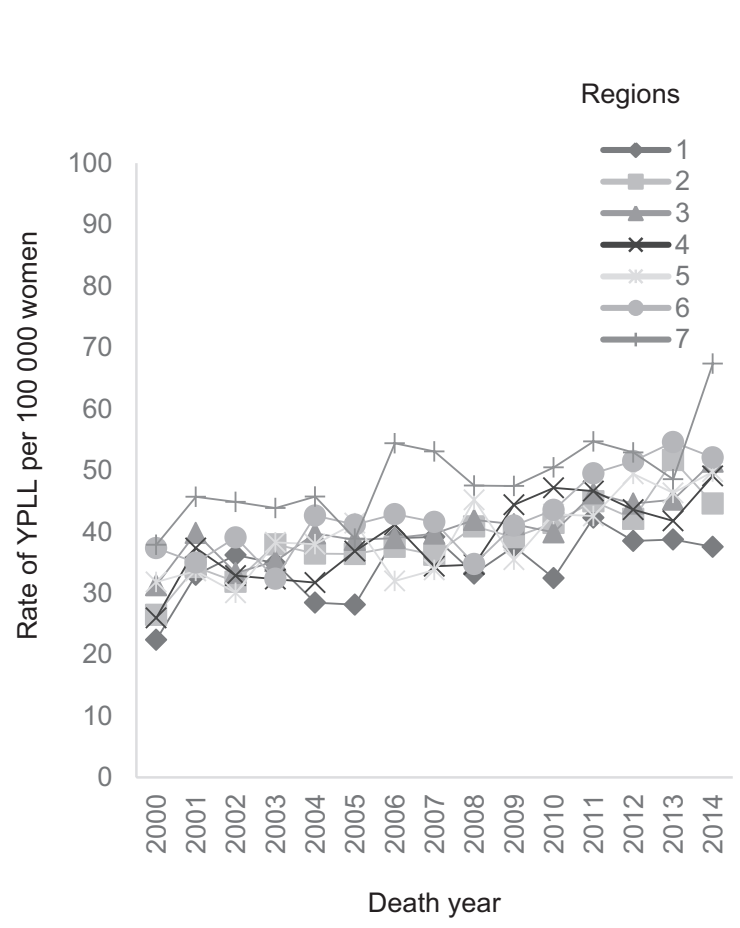

Figure 3. Rate of years of potential life lost due to ovarian cancer by socioeconomic region. Mexico, 2000-2014. YPLL rate per 100,000 women adjusted for age using the national population as standard reference population.

which corresponds, for example, to life expectancy at birth in the studied population. Considering the age at which people die and not just the event of death itself, allows assigning a different weight to deaths that occur at different moments of life. The assumption on which YPLLs are based is that the more "premature" death is, the greater life loss is, some of which are sensitive to health and social measures. ${ }^{12}$

The American Society of Gynecologic Oncology recommends the following strategies for OC prevention:16

- Use of oral contraceptives.

- Tubal occlusion.

- Risk reduction by means of salpingo-oophorectomy in women with high hereditary breast and ovarian cancer risk,

- Genetic counseling and genetic testing for women with high family $\mathrm{OC}$ risk.

- Salpingectomy once parity is satisfied.

\section{Conclusions}

In the study period, 25047 women died of OC, the mortality rate, standardized by age with the world population per 100000 women, increased from 3.3 to 4.1 , with a percentage change of $24.2 \%$ and an average annual change of $0.043,95 \% \mathrm{Cl}=0.32-0.55$. In the study period, the states and the socioeconomic region 
that had the highest mortality rates were Chihuahua (2000), Baja California Sur (2001, 2002, 2007 and 2009), Colima (2003, 2005, 2011, 2012), Quintana Roo (2004), Zacatecas (2006), Sonora (2008), Coahuila (2010), Aguascalientes (2013), Querétaro (2014) and region 7 . The states and regions that showed the highest YPLL rate in the study period were Nayarit (2000), Baja California Sur (2001 and 2007), Zacatecas (2002), Colima (2003, 2004 and 2010), Tlaxcala (2005), Zacatecas (2006), Oaxaca (2008), Quintana Roo (2009), Coahuila (2011-2012), Querétaro (2014) and regions 7 (2000-2004, 2006-2012, 2014), 5 (2005) and 6 (2013).

\section{References}

1. Ovarian Cancer 2014 Report. Food, nutrition, physical activity, and the prevention of ovarian cancer. Reino Unido: World Cancer Research Fund/American Institute for Cancer Research; 2014. Disponible en: www. wcrf.org/sites/default/files/Ovarian-Cancer-2014-Report.pdf

2. Malvezzi M, Carioli G, Rodríguez T, Negri E, La-Vecchia C. Global trends and predictions in ovarian cancer mortality. Ann Oncol. 2016;27:2017-2025.

3. Rivas-Corchado LM, González-Geroniz M, Hernández-Herrera RJ. Epidemiological profile of ovarian cancer. Ginecol Obstet Mex. 2011; 79:558-564.

4. Torres-Sánchez LE, Rojas-Martínez R Escamilla-Núñez C Vara-Salazar E, Lazcano-Ponce E. Tendencias en la mortalidad por cáncer en México de 1980 a 2011. Salud Publica Mex. 2014;56:473-491.

5. Instituto Nacional de Estadística y Geografía. Registros administrativos de mortalidad. México: Instituto Nacional de Estadistica y Geografía 2016. Disponible en: http://www3.inegi.org.mx/sistemas/microdatos/encuestas.aspx?c=33398\&s=est

6. World Health Organization. International Statistical Classification of Diseases and Problems Related to Health, $10^{\text {th }}$ review. Ginebra, Suiza: World Health Organization; 1995.

7. Inskip H, Beral V, Fraser P, Haskey J. Methods for age-adjustment of rates. Stat Med. 1983:2:455-466.

8. Ahmad OB, Boschi-Pinto C, López AD, Murray CJL, Lozano R, Inoue M Age standardization of rates: a new WHO standard. En: Global Pro- gramme on Evidence for Health Policy Discussion Paper Series no. 31 Ginebra, Suiza: World Health Organization; 1999.

9. Instituto Nacional de Estadistica y Geografía. Regiones socioeconómicas de México México: Instituto Nacional de Estadistica y Geografía; 2000. Disponible en :http://sc.inegi.org.mx/niveles/datosnbi/reg_soc_mexico.pdf

10. Consejo Nacional de Población. Estimaciones demográficas 1990-2010 y proyecciones de la población 2010-2050. México: Consejo Nacional de Población; 2014. Disponible en. http://www.conapo.gob.mx/es/CONAPO/Proyecciones_Datos.

11. Jensen OM, Parkin DM, MacLennan R, Muir CS, Skeet RG. Cancer registration: principles and methods. Francia: International Agency for Research on Cancer; 1995.

12. Pan American Health Organization. Techniques to measure the impact of mortality: years of potential life lost. Epidemiological Bulletin. 2003; $24: 1-4$.

13. Romeder JM, McWhinnie JR. Potential years of life lost between ages 1 and 70: an indicator of premature mortality for health planning. Int $\mathrm{J}$ Epidemiol. 1977:6:143-151.

14. Hervada-Vidal X, Santiago-Pérez M, Vázquez-Fernández E, Castillo-Salgado C, Loyola-Eñizondo E, Silva-Ayçaguer LC. Epidat 3.0 Programa para análisis epidemiológico de datos tabulados. Rev Esp Salud Publica. 2004:78:277-280.

15. Hunn J, Rodríguez GC. Ovarian cancer: etiology, risk factors, and epidemiology. Clin Obstet Gynecol. 2012;55:3-23.

16. Walker JL, Powell CB, Chen LM, Carter J, Bae-Jump VL, Parker LP, et al. Society of Gynecologic Oncology recommendations for the prevention of ovarian cancer. Cancer. 2015;121:2108-2120.

17. Smith ER, Xu XX. Ovarian ageing, follicle depletion, and cancer: a hypothesis for the aetiology of epithelial ovarian cancer involving follicle depletion. Lancet Oncol. 2008;9:1108-1111.

18. Song $\mathrm{H}$, Cicek MS, Dicks E, Harrington $\mathrm{P}$, Ramus SJ, Fridley BL, et al. The contribution of deleterious germline mutations in BRCA1, BRCA2 and the mismatch repair genes to ovarian cancer in the population. Hum Mol Genet. 2014;23:4703-4709.

19. Reid BM, Permuth JB, Sellers TA. Epidemiology of ovarian cancer: a review. Cancer Biol Med. 2017:14:9-32.

20. Encuesta Nacional de Salud y Nutrición de Medio Camino 2016. Informe final de resultados. México: Secretaría de Salud/Instituto Nacional de Salud Pública; 2016.

21. Kuri-Morales $\mathrm{P}$, Emberson J, Alegre-Díaz J, Tapia-Conyer R, Collins R, Peto R, et al. The prevalence of chronic diseases and major disease risk factors at different ages among 150000 men and women living in Mexico City: cross-sectional analyses of a prospective study. BMC Public Health. 2009;9:9.

22. Reynales-Shigematsu L, Valdés-Salgado R, Rodríguez-Bolaños R, Lazcano-Ponce E, Hernández-Avila M. Encuesta de tabaquismo en jóvenes en México. Análisis descriptivo 2003, 2005, 2006, 2008. México: Instituto Nacional de Salud Pública/Secreataría de Salud/Comisión Nacional contra las Adicciones; 2009. 